GRASAS Y ACEITES 71 (3)

July-September 2020, e373

ISSN-L: 0017-3495

https://doi.org/10.3989/gya.0572191

\title{
Study of water deficit conditions and beneficial microbes on the oil quality and agronomic traits of canola (Brassica napus L.)
}

\author{
H. Keshavarz ${ }^{\square}$ \\ Agronomy Department, Faculty of Agriculture, Tarbiat Modares University, Iran \\ Corresponding author: H.Keshavarz@Modares.ac.ir
}

Submitted: 23 May 2019; Accepted: 24 September 2019; Published online: 27 August 2020

\begin{abstract}
SUMMARY: Water deficit stress is one of the major limiting factors that adversely affect plant growth and yield production. Some rhizosphere bacteria are known to promote plant growth in such stressful conditions. To study the response of quantifying canola growth, yield and yield components, to root colonization by two species of mycorrhizal fungi, a two-year field experiment was conducted at the research farm of Zanjan University. The main plot conditions were irrigation at $85 \%\left(\mathrm{~S}_{1}\right), 70 \%\left(\mathrm{~S}_{2}\right)$ and $55 \%\left(\mathrm{~S}_{3}\right)$ of field capacity which were defined as no stress, mild and severe stress. The subplot treatments included three levels of mycorrhizal inoculation: non inoculation (control), G. mosseae and G. intraradices. The results showed that regardless of water deficit stress, colonized plants produced more biomass, seed and oil yield than non inoculated plants. Water deficit stress reduced the RWC and oil percentage of the seeds, although mycorrhizal improved these traits. Water deficit strikingly decreased the linoleic acid content in the seeds in contrast with increased stearic, oleic, arachidic and linolenic acids in the canola seeds. The presence of bacteria increased the seed oil percentage, oleic and linoleic contents. However, it decreased arachidic, particularly when the plants were subjected to water deficit stress.
\end{abstract}

KEYWORDS: Drought; Mycorrhizal Symbiosis; Oil Yield; Rapeseed; Unsaturated Fatty Acid

RESUMEN: Estudio del déficit hídrico y microorganismos beneficiosos sobre la calidad del aceite y las características agronómicas de la canola (Brassica napus $L$.). El estrés por déficit hídrico es uno de los factores limitantes más importantes que afectan negativamente al crecimiento de las plantas y al rendimiento. Se sabe que algunas bacterias de la rizosfera promueven el crecimiento de las plantas en condiciones estresantes. Para estudiar el crecimiento de la canola, el rendimiento y los componentes del rendimiento, a la colonización de la raíz por dos especies de hongos micorrícicos, se realizó un experimento de campo de dos años en la granja de investigación de la Universidad de Zanjan. Las principales condiciones de la parcela fueron el riego al 85\% (S1), 70\% (S2) y $55 \%$ (S3) de la capacidad de campo, que se definió como sin estrés, estrés leve y severo. Los tratamientos de la subparcela incluyeron tres niveles de inoculación micorrízica: no inoculación (control), G. mosseae y G. intraradices. Los resultados mostraron que, independientemente del estrés por déficit hídrico, las plantas colonizadas producían más biomasa, semillas y rendimiento de aceite que las plantas no inoculadas. El estrés por déficit hídrico reduce el RWC y el porcentaje de semillas oleaginosas, aunque la micorriza mejoró estos rasgos. La existencia de déficit hídrico disminuyó notablemente el contenido de ácido linoleico de la semilla en contraste, aumentaron los ácidos esteárico, oleico, araquídico y linolénico en las semillas de canola. La presencia de bacterias aumentó el porcentaje de aceite de semilla, el contenido de oleico y linoleico. Sin embargo, disminuye el araquídico particularmente cuando las plantas fueron sometidas a estrés de déficit de agua.

PALABRAS CLAVE: Ácido graso insaturado; Colza; Rendimiento de aceite; Sequía; Simbiosis micorrízica

ORCID ID: Keshavarz H https://orcid.org/0000-0002-7607-1580

Citation/Cómo citar este artículo: Keshavarz H. 2020. Study of water deficit conditions and beneficial microbes on the oil quality and agronomic traits of canola (Brassica napus L.). Grasas Aceites 71 (3), e373. https://doi.org/10.3989/ gya.0572191

Copyright: (02020 CSIC. This is an open-access article distributed under the terms of the Creative Commons Attribution 4.0 International (CC BY 4.0) License. 


\section{INTRODUCTION}

Drought is one of the main restrictions on the quantity and quality of crop productivity throughout the world. Moreover, changes in global climate suggest an increase in aridity, especially arid and semi arid regions in the future (Huang et al., 2016). Depending on the severity of stress (ranging from short and moderate to extremely severe) and duration, drought stress limits crop yield (MartínezBallesta et al., 2013). It is assumed that drought will have caused yield loss and crop damage in more than $50 \%$ of arable land by 2050 (Martínez-Ballesta et al., 2013). Drought interferes with the normal function of plants due to changing in turgor and plant water potential (Rahdari and Hoseini, 2012). Previous studies have shown the growth reduction under drought stress in several crops such as maize (Chen et al., 2012) and rape seed (Safavi Fard et al., 2018; Nazeri et al., 2018). Variation in chlorophyll and relative water content (RWC) are often measured because they are affected by stress and expected to be a symptom of the photooxidation of drought injury (Keshavarz et al., 2018). As nutrients are carried through water, in drought conditions they are less mobile. In fact, reduced cell division and cell elongation are due to a decline in ion and water transfer to the roots (Anjum et al., 2011). Among the various impacts of drought stress, its effects on plant growth and crop damage in arid and semi arid ecosystem are generally discussed (Anjum et al., 2011).

Rapa seed canola (Brassica napus L.) is one of the most widely cultivated oil crops because it is very healthy edible oil which contains a low component of saturated fatty acid (5-7\%) and high component of polyunsaturated fatty acid $(7-10 \%$ and $17-21 \%$, linolenic and linoleic acid, respectively) (Baux et al., 2008). The yield and profile compositions of oil seeds are vary greatly with growing condition, location and year. Therefore, any environmental stress like cold, heat and drought may affect fatty acid composition, especially linolenic acid contents (Gunasekera et al., 2006). In terms of seed composition, it has been found that oil concentration decreases in response to water stress and vice versa (Aslam et al., 2009). In order to produce a good quality oil seed with high oil yield, it is necessary to manage water and nutrient ability. It is also worth mentioning that other factors including genotype, environmental parameters and interaction between them also affect the fatty acid composition (Safavi Fard et al., 2018). Fatty acids are the main components of vegetable oil including saturate and unsaturated acids. Among them, linoleic and linolenic acids are the most important part of the fatty acid composition because they are not produced by the human body, so they are dietary essentials (Gunasekera et al., 2006). The biochemical pathway of desaturation starts from steric acid, followed by oleic and linoleic acids and ending with desaturation to linoleic acid (Steen et al., 2010). It seems that the stress severity would be critical to a change in fatty acid composition and low moisture or the nutritional situation may inhibit the activity of oleate desaturase. It has been reported that mild water stress increased unsaturated fatty acids but acute stress decreased its content (Aslam et al., 2009). In drought conditions, an increase in oleic/linoleic acid ratio has been reported compared to favorable water regimes (Baux et al., 2008). Therefore, accumulation in saturated fatty acid would be the result of injury caused by acute drought stress and possibly, increased drought tolerance (Zhang et al., 2005). However, a positive correlation between oleic acid content and water use can be observed in plants submitted to drought stresses (Aslam et al., 2009). On the other hand, Zhang et al., (2005) reported an increase in the oleic/linoleic acid ratio under water stress, while some researchers observed no effect of drought stress on oleic acid content (Eyni-Nargeseh et al., 2019).

Several studies have shown that the application of free living Plant Growth Promoting Rhizobaacteria (PGPR) such as Azospirillum, Burkholderia, Bacillus, and Enterobacter are not only effective in terms of better nutrition balance but can also increase drought stress tolerance by various mechanisms including volatile compounds, phytohormonal activity, 1-aminocyclopropane-1-carboxylic acid (ACC) deaminase activity, alteration in root morphology and antioxidant defense (Kaushal and Wani, 2016). Moreover, fungal treatment can effectively improve plant growth and development by supplying the restricted nutrition (Ahemad and Kibret, 2014). Among them, PGPR can enhance the synthesis of phytohormones like auxin, gibberellins, cytokinin (Cohen et al., 2009; Figueiredo et al., 2008). The production of Indoleacetic acid (IAA), which is stimulated by mycorrhiza species may increase the effects of endogenous auxin and enhance root growth, surface area and number of root tips by motivating cell division and elongation, which lead to improved plant ability to water and nutrient uptake (Mantelin and Touraine, 2004). Increased plant tolerance to environmental stress with PGPR might be due to the fact that PGPR can help reduce the content of ethylene by the production of ACC deaminase which prevents the synthesis of ethylene by cleavage of the ethylene precursor (Kaushal and Wani, 2016). Rhizosphere fungi can provide iron by the production of siderophores that chelate ferric iron $\left(\mathrm{Fe}^{3+}\right)$ and make it available for plant cells (Arora et al., 2001). The solubilization of phosphates is the other beneficial fungal capability which can solubilize mineral phosphate from insoluble compounds (Bouwmeester et al., 2007). Casanovas et al., (2002) showed that plant 
inoculation with biofertilizers obtained better relative and absolute water contents compared to non inoculated plants under water restricted stress. Fungal treatment increased biomass, root growth and chlorophyll content (Casanovas et al., 2002). A colonization treatment in wheat (Triticum aestivum) and Brassica species under drought resulted in better grain yields and higher $\mathrm{Mg}, \mathrm{K}$ and $\mathrm{Ca}$ in the seeds, suggesting that water status plays important role in enhanced drought tolerance in plants (Creus et al., 2004; Arvin et al., 2012). It has also been shown that the relationship between fungus and root enhances the chlorophyll content under water shortage conditions. As a result of the increased chlorophyll content in plant inoculation with fungi, higher yields are obtained compared to non-fungal treatment (Casanovas et al., 2002).

The effects of rhizosphere microbes on various crops have been described previously, but there is very little knowledge about the effect of PGPR on canola seed oil composition under drought stress. Therefore, the aim of the present study was to define the rule of mycorrhiza on the quality and quantity of canola oil yield and various parameters related to yield under mild and extreme drought stress.

\section{MATERIALS AND METHODS}

\subsection{Experimental description and soil sampling}

This experiment was conducted in the research field of the Agriculture faculty of Tarbiat Modares University, Tehran, Iran, during two crop seasons (2014-2015 and 2015-2016, referred hereafter as 2015 and 2016, respectively). Weather conditions, such as temperature and precipitation were obtained from Chitgar $\left(51^{\circ} 10^{\prime} \mathrm{E}, 33^{\circ} 44^{\prime} \mathrm{N}, 1305.2 \mathrm{~m}\right.$ above sea level) weather station which is located $1 \mathrm{~km}$ from the field condition. The climate is semi-arid with a hot dry summer and cool winter. The monthly precipitation and mean air temperature during the period of October-July and long-term average are shown in Table 1. In both years, the precipitation was lower compare to longer periods of time due to uneven distribution, which mostly happens during the autumn and winter months. Mean annual air temperature in the second growing season was $13.6^{\circ} \mathrm{C}$, which was similar to long-term meteorological data; while in first growing season the mean temperature $\left(14.2^{\circ} \mathrm{C}\right)$ was higher than the longterm (data not shown). One week before sowing, the experimental field soil was sampled from 0-30 and $30-60 \mathrm{~cm}$ depth, air-dried, crushed and passed through a $2 \mathrm{~mm}$ riddle to determine the soil properties. Soil EC and $\mathrm{pH}$ were determined in 1:2 soil:water suspension; organic matter was measured based on sulphuric acid (Walkley and Black, 1934) and total nitrogen was determined by the Kjeldahl method. The concentrations of available phosphorus and potassium were estimated after extraction with ammonium acetate (Qian et al., 1994). The soil was sandy loam. The details of the soil characteristics are given in Table 2.

\subsection{Experimental set up}

The herbicide trifluralin (Treflan) at 1.2 1/ha was applied to the soil for pre-emergence weed control and the field was prepared for the seedbed by plowing and disking. Based on soil analysis, there was no need for phosphorus or potassium fertilizer (Table 2). Each individual subplot was $4 \mathrm{~m}$ long and 1.75 wide, consisting of six rows $(35-\mathrm{cm}$ row spacing) and $5-\mathrm{cm}$ intervals in the row. Half a meter from each side was considered as the border. The plant density was 60 seeds $\cdot \mathrm{m}^{-2}$. The final plant population was kept at approximately 600,000 plants $^{-h^{-1}}$ by thinning the seedlings at the six-leaf stage. There was a 1-m gap and 2-m alley for each plot and block, respectively, for lateral water movement and other interferences. All treatments were applied to the same plot in two years to find out the treatment effects. The amount

TABLE 1. Precipitation and monthly mean temperatures during 2014 and 2015 and their long-term averages (10 years).

\begin{tabular}{|c|c|c|c|c|c|c|c|c|c|c|}
\hline Months & October & November & December & January & February & March & April & May & June & July \\
\hline \multicolumn{11}{|l|}{ 2014-2015 } \\
\hline M.A.T. $\left({ }^{\circ} \mathrm{C}\right)$ & 18.2 & 10.4 & 4.2 & -2 & 3.2 & 6.1 & 11.6 & 15.8 & 23.8 & 27.2 \\
\hline Rain (mm) & 11.2 & 52.1 & 68.1 & 81.4 & 71.2 & 68.6 & 56.4 & 46.1 & 1.2 & 0.0 \\
\hline \multicolumn{11}{|l|}{ 2015-2016 } \\
\hline M.A.T. $\left({ }^{\circ} \mathrm{C}\right)$ & 17.7 & 11 & 3.7 & -2.5 & -2.2 & 5.8 & 9.6 & 14.2 & 21.2 & 25.2 \\
\hline Rain (mm) & 38.6 & 41.7 & 55.4 & 48.2 & 79.6 & 52.1 & 42.3 & 35.2 & 0.0 & 0.0 \\
\hline \multicolumn{11}{|l|}{ longer period } \\
\hline M.A.T. $\left({ }^{\circ} \mathrm{C}\right)$ & 17.3 & 10.5 & 4.9 & 1.3 & 0.9 & 5.2 & 10.7 & 15.2 & 21.2 & 26.6 \\
\hline M.R. (mm) & 11.9 & 59.5 & 73.5 & 72.4 & 79 & 81.6 & 64 & 34.3 & 2.1 & 0.6 \\
\hline
\end{tabular}

M.A.T. $=$ mean air temperature; M.R. $=$ mean rainfall.

Canola was planted on 22 October, 2014 and 03November, 2015. 
TABLE 2. Physico-chemical properties of the soil.

\begin{tabular}{|c|c|c|c|c|}
\hline \multirow[b]{3}{*}{ Properties } & \multicolumn{4}{|c|}{ Depth (cm) } \\
\hline & \multicolumn{2}{|c|}{ 0-30 } & \multicolumn{2}{|c|}{$30-60$} \\
\hline & 2015 & 2016 & 2015 & 2016 \\
\hline $\mathrm{EC}^{1}\left(\mathrm{dS} \cdot \mathrm{m}^{-1}\right)$ & 1.6 & 1.2 & 1.4 & 1.3 \\
\hline pH (water 1:2 ratio) & 7.7 & 7.4 & 7.1 & 7.2 \\
\hline $\operatorname{CEC}^{2}\left(\mathrm{meq} \cdot 100^{-1} \mathrm{~g}\right)$ & 5.7 & 6.0 & 4.1 & 4.0 \\
\hline Organic matter (\%) & 0.9 & 0.11 & 0.8 & 0.7 \\
\hline Sand $(\%)$ & 66 & 64 & 61 & 59 \\
\hline Silt $(\%)$ & 19 & 19 & 28 & 31 \\
\hline Clay (\%) & 15 & 17 & 11 & 10 \\
\hline Organic matter $(\%)$ & 0.4 & 0.6 & 0.3 & 0.4 \\
\hline $\mathrm{N}(\%)$ & 0.06 & 0.11 & 0.04 & 0.05 \\
\hline $\mathrm{P}\left(\mathrm{mg} \cdot \mathrm{kg}^{-1}\right)$ & 6.9 & 8.3 & 2.3 & 2.1 \\
\hline $\mathrm{K}\left(\mathrm{mg} \cdot \mathrm{kg}^{-1}\right)$ & 296 & 323 & 186 & 180 \\
\hline $\mathrm{Fe}\left(\mathrm{mg} \cdot \mathrm{kg}^{-1}\right)$ & 6.5 & 7.2 & 3.4 & 3.3 \\
\hline $\mathrm{Zn}\left(\mathrm{mg} \cdot \mathrm{kg}^{-1}\right)$ & 1.1 & 0.8 & - & - \\
\hline Field capacity $(\%)$ & 16 & 17 & - & - \\
\hline Crop extractable water $(\%)$ & 10 & 10 & - & - \\
\hline Available water (\%) & 13 & 12 & - & - \\
\hline
\end{tabular}

${ }^{1} \mathrm{EC}=$ Electrical conductivity.

${ }^{2} \mathrm{CEC}=$ Cation exchange capacity.

of canola seeds was $5 \mathrm{~kg} \cdot \mathrm{ha}^{-1}$. According to local recommendation and total residual soil $\mathrm{N}$ in the top soil $\left(50 \mathrm{~kg} \cdot \mathrm{ha}^{-1}\right), \mathrm{N}$ was applied from a granular urea fertilizer $\left(125 \mathrm{~kg} \cdot \mathrm{ha}^{-1}\right)$ as its $\mathrm{N}$ source and was applied by hand at three time points: $25 \mathrm{Kg} \cdot \mathrm{ha}^{-1}$ at the time of sowing (starter) and then top dressed at the 5-6-leaf rosette stage and the flower bud stage in both years. Insects and pests were controlled as required after seeding based on common regional practices and the plants were routinely inspected during the summer for insect damage. The seeds were inoculated and sown in late October to early November in both years (the usual time for sowing canola in Karaj) by hand. at a depth of $2.0 \mathrm{~cm}$. The plots were hand weeded as necessary with a hoe and/ or tiller.

\subsection{Treatment application}

A split plot design was arranged on a completely randomized block in three replicates. Three levels of irrigation regimes were applied to the main plot. The mycorrhiza treatments consisted of G. mosseae, G. intraradices and no inoculation (control) was allocated for the subplots. The rapeseeds (canola cv. Okapi, provided by Seed and Plant Certification and Registration Institute, Karaj, Iran) were sterilized by soaking them in $90 \%$ ethanol for 30 s and rinsing precisely in four changes of sterile distilled water. Two strains of PGPR were determined to be commercially available in Iran for fungi treatment: the arbuscular mycorrhiza strains Glomus mosseae and Glomus intraradices. These mycorrhiza isolates came from the Soil and Water Researcher institute, Karaj, Iran. According to the manufacturer's recommendation, inoculation was performed by soaking the canola seeds in suspension adjusted to $10^{9} \mathrm{CFU} \cdot \mathrm{ml}^{-1}$ with sterile normal saline $(0.9 \% \mathrm{NaCl})$ for 4 hours at $28{ }^{\circ} \mathrm{C}$ before sowing. Control plants were inoculated with sterilized water.

A drip irrigation system was used to water all treatments with light irrigations $(5 \mathrm{~mm})$ every two days for 5 weeks to ensure uniform seed germination and plant emergence until the rosettes were well established. The irrigation regimes were started early spring (April $4^{\text {th }}$, both years, flowering stage) and continued throughout the season (ending mid July, both years). The actual amount of irrigation was decreased according to weather conditions, so the irrigation routine was interrupted because of periodic rainfall.

The plots were irrigated at $85 \%$ field capacity (no stress), 70\% field capacity (mild stress) and $55 \%$ field capacity (sever stress). Irrigation water needed prior to irrigation $\left(\mathrm{V}_{\mathrm{w}}\right.$ in $\left.\mathrm{m}^{3}\right)$ was estimated based on the soil's water content $\left(\theta_{i}\right)$ using the TDR method (Time Domain Reflectometry, model 4593, soil moisture equipment, Santa Barbara) and effective rooting depth (D, $0.6 \mathrm{~m}$ here) according to the following equation (1) (Mokhtassi-Bidgoli et al., 2013):

$$
\mathrm{V}_{\mathrm{w}}:\left(\theta_{\mathrm{F} . \mathrm{C}}-\theta_{\mathrm{i}}\right) \times \mathrm{D} \times \mathrm{A}
$$

Where, $\theta_{\text {F.C }}$ is the volume of soil moisture at field capacity and $\mathrm{A}$ is the main plot area (m). TDR probes were inserted into vertical holes of $5-6 \mathrm{~cm}$ in diameter and $80 \mathrm{~cm}$ deep which were dug using a hand auger in the middle of each plot. Data on the volumetric water content were collected daily prior to setting the experiment to calibrate before seed sowing and during the growing season to calculate the time of irrigation. The amount of irrigation applied was according to the soil deficit to bring it back to field capacity and runoff was supposed to be negligible. The total of irrigation water consumed during the growing season recorded by a volume counter was 5120,4265 and $3312 \mathrm{~m}^{3}$ water $\cdot \mathrm{ha}^{-1}$ in 2014 and in 2015 it was 5421, 4502 and 3564, for $\mathrm{I}_{1}, \mathrm{I}_{2}$ and $\mathrm{I}_{3}$, respectively.

\subsection{Data collection}

Eight weeks after the initiation of drought stress (early grain filling stage), the relative water contents of leaves (RWC) and the content of leaf chlorophyll (SPAD value, SPAD-502 Minolta, Japan) were calculated. To determine the RWC, six fully expanded young leaves from each plot were detached and weighed (fresh weight, FW). The same leaves were 
immersed in distilled water and allowed to rehydrate for $12 \mathrm{~h}$ at room temperature. Afterwards, their turgid weights (TW) were measured. Then the samples were dried in an oven at $70{ }^{\circ} \mathrm{C}$ for $24 \mathrm{~h}$ to obtain their dry weight (DW). Relative water contents were calculated by using the following equation (2):

$$
\frac{\mathrm{FW}-\mathrm{DW}}{\mathrm{TW}-\mathrm{DW}} \times 100
$$

After the $95^{\text {th }}$ day of drought stress induction, $1 \mathrm{~m}^{2}$ of plants from the middle of each plot were selected for yield and yield component determination to avoid side effects. To minimize potential yield losses associated with delayed harvest, the plots were harvested by hand when the pods dried and became hard and their color had changed from green to dark reddish brown. The majority of the seeds had a moisture content of 14-16\%. All harvested samples (seed and biomass) were oven-dried at $70{ }^{\circ} \mathrm{C}$ for $72 \mathrm{~h}$ and weighed.

Seed moisture was defined and seed yield was adjusted to a $10 \%$ moisture basis. Seed samples were taken for the determination of seed oil content using an Inframatic 8620 (Percore, Germany). Oil yield was calculated by multiplying the product of seed yield and seed oil percentage.

The oil sample for each treatment was converted to methyl esters in the presence of Menthol/ $\mathrm{BF}_{3}(14 \% \mathrm{w} / \mathrm{w})$ reagent and using sodium methoxide as catalyst (Budge and Barry, 2019). 200-mg oil samples were added to $7 \mathrm{ml}$ sodium methylate $(0.5 \mathrm{M})$ and heated to boiling for $10 \mathrm{~min}$. After that $5 \mathrm{ml}$ Boron tri fluoride in menthol were added to the mixture. It was heated again for $2 \mathrm{~min}$ and $6 \mathrm{ml}$-hexane (GC grade) were added to the complex and heated for $2 \mathrm{~min}$. Finally, $50 \mathrm{ml}$ saturated saline water were added and the suspension was shaken vigorously for $1 \mathrm{~min}$. The upper phase $(0.5 \mu 1)$ was taken and analyzed by GC (GC 8000, Carlo-Erba Instruments, Italy) equipped with a flam ionization detector (FID) on a DB23 fused silica capillary column ( $30 \mathrm{~m}$ by $0.25 \mathrm{~mm}$ i.d., $\mathrm{d}_{\mathrm{r}}=0.25 \mu \mathrm{m}$ film; J and W Scientific, Folsom, CA). Nitrogen was used as carrier gas at a flow rate of $4.93 \mathrm{ml} / \mathrm{min}$ and the split ratio was $21.28 \mathrm{ml} \cdot \mathrm{min}^{-1}$. The GC process was conducted in split mode injection at an oven temperature of $120^{\circ} \mathrm{C}$ for 1 min, raised to $220{ }^{\circ} \mathrm{C}$ for $15^{\circ} \mathrm{C} \cdot \mathrm{min}^{-1}$ then kept at $220{ }^{\circ} \mathrm{C}$ for $15 \mathrm{~min}$. The injector and detector temperature were set at $250{ }^{\circ} \mathrm{C}$. Peak identification was performed by comparison with the retention time of valid commercial standards (Sigma Co., USA). The fatty acid contents of stearic acid (C 18:0, STA), oleic acid (C 18:1, OLA), linoleic acid (C 18:2, LINO), arachidic acid (C 20:0, ARA) and linolenic acid (C 18:3, LINK) were shown as a percentage of the oil.

\subsection{Statistical analysis}

All data were subjected to a two-way analysis of variance (ANOVA). A slice test was done to determine the quality of the simple effects of the factors for each level of other factors. The significance of differences among main treatment effects and their interaction were determined by the LSD test with the level of significance established at $p \leq 0.05$. Seasons were analyzed separately because the Bartlett test was significant for most traits measured. All analyses were performed using the SAS (SAS release 9.0 2002) software.

\section{RESULTS}

Meteorology data showed that the rainfall and temperature of the growing seasons were different over the two years (Table 1). In the 2014-2015 growing season (Oct-Jul), the mean monthly air temperature was higher than the long-term temperature (average) except in January; whereas in 2015-2016, the mean monthly temperature was slightly lower than normal air temperature. Precipitations in both years were well below or near the long-term average (expect May). Precipitation was higher the first year than the second year. High air temperature was observed during the seed filling period in the first growing season (April-June) and the difference in rainfall during the growing season could be the reason for the significant interaction between year and treatment and for yield and yield components. Therefore, the results of these traits are presented for each year separately.

The analysis of variance showed that treatments were affected by year, drought stress, mycorrhiza treatment and their interaction except for the effect of year on SPAD, relative water content, biological yield, STA and LINO and the effect of the mycorrhiza treatment on LINK (Table 3). There was not a significant year $\times$ drought and year $\times$ mycorrhiza interaction for all treatments. Therefore, the main effects of treatments and their interactions are discussed below for yield and yield components for each year separately (Tables 4, 5 and 6).

\subsection{SPAD value and relative water content (RWC)}

The results showed that SPAD and RWC content were lower in the plants under drought stress (Table 4). When compared with normal condition, mild and severe drought stress reduced the RWC by 6 and 9\% in 2014 and $6 \%$ and in 2015. Indeed, during both years, the RWC decreased linearly with increasing drought stress severity (Table 4). Regardless of drought stress, in both experimental years, the main effects of mycorrhiza inoculation increased the SPAD and RWC contents when compared to the non inoculation treatment. 
TABLE 3. Analysis of variance (mean squares) for the main and interaction effects of water deficit stress (S) and Mycorrhiza (M) on the SPAD, RWC, yield and yield components of canola.

\begin{tabular}{|c|c|c|c|c|c|c|c|}
\hline Sources of Variance & df & SPAD & RWC & Seed Weight & Seed Yield & Oil content $(\%)$ & Oil Yield \\
\hline Year & 1 & $8.08 \mathrm{~ns}$ & $0.39 \mathrm{~ns}$ & $2.5 * *$ & $2451204.1 * *$ & $260.2 * *$ & $2102941.8 * *$ \\
\hline Replication $\times$ Year & 4 & 11.95 & 3.55 & 0.10 & 54362.7 & 0.43 & 8519.5 \\
\hline water deficit stress (S) & 2 & $3029.8 * *$ & $386.3 * *$ & $11.02 * *$ & $12814830.8 * *$ & $39.7 * *$ & $3757501.1 * *$ \\
\hline Year $\times S$ & 2 & $4.71 \mathrm{~ns}$ & $5.84 \mathrm{~ns}$ & $0.0053 \mathrm{~ns}$ & $8813.9 \mathrm{~ns}$ & $0.012 \mathrm{~ns}$ & $9439.8 \mathrm{~ns}$ \\
\hline Replication $\times \mathrm{S} \times$ Year & 8 & 27.49 & 10.25 & 0.091 & 785892.1 & 0.14 & 188594.5 \\
\hline Mycorrhiza (M) & 2 & $320.6 * *$ & $154.04 * *$ & $2.13 * *$ & $2897726.2 * *$ & $4.28 * *$ & $734698.6 * *$ \\
\hline $\mathrm{S} \times \mathrm{M}$ & 4 & $15.1 *$ & $6.09 \mathrm{~ns}$ & $0.13 *$ & $81192.0 \mathrm{~ns}$ & $1.82 * *$ & $14334.2 \mathrm{~ns}$ \\
\hline Year $\times$ M & 2 & $4.8 \mathrm{~ns}$ & $0.66 \mathrm{~ns}$ & $0.00067 \mathrm{~ns}$ & $1026.8 \mathrm{~ns}$ & $0.001 \mathrm{~ns}$ & $812.5 \mathrm{~ns}$ \\
\hline Year $\times \mathrm{S} \times \mathrm{M}$ & 4 & $2.75 \mathrm{~ns}$ & $1.17 \mathrm{~ns}$ & $0.00016 \mathrm{~ns}$ & $649.99 \mathrm{~ns}$ & $0.001 \mathrm{~ns}$ & $460.7 \mathrm{~ns}$ \\
\hline Error & 24 & 4.1 & 3.68 & 0.034 & 90212.6 & 0.19 & 17199.4 \\
\hline CV (\%) & & 3.53 & 2.24 & 4.05 & 6.71 & 0.95 & 6.31 \\
\hline SOV & df & Biological Yield & STA & OLA & LINO & ARA & LINK \\
\hline Year & 1 & $4159447.6 \mathrm{~ns}$ & $0.0043 \mathrm{~ns}$ & $5.80 *$ & $7.077 \mathrm{~ns}$ & $0.07 * *$ & $0.00027 \mathrm{~ns}$ \\
\hline Replication $\times$ Year & 4 & 1294607.4 & 0.052 & 0.36 & 1.37 & 0.002 & 0.32 \\
\hline water deficit stress (S) & 2 & $150273516.7 * *$ & $2.34 * *$ & $7.03 * *$ & $9.45 * *$ & $0.14 * *$ & $0.55 *$ \\
\hline Year $\times S$ & 2 & $47080.5 \mathrm{~ns}$ & $0.041 \mathrm{~ns}$ & $0.037 \mathrm{~ns}$ & $0.078 \mathrm{~ns}$ & $0.001 \mathrm{~ns}$ & $0.32 \mathrm{~ns}$ \\
\hline Replication $\times \mathrm{S} \times$ Year & 8 & 2660498.1 & 0.04 & 0.19 & 0.49 & 0.001 & 0.16 \\
\hline Mycorrhiza (M) & 2 & $25657189.7 * *$ & $0.63 * *$ & $1.17 * *$ & $3.47 * *$ & $0.05 * *$ & $0.12 \mathrm{~ns}$ \\
\hline $\mathrm{S} \times \mathrm{M}$ & 4 & $346959.3 \mathrm{~ns}$ & $0.02 \mathrm{~ns}$ & $0.14 \mathrm{~ns}$ & $0.33 \mathrm{~ns}$ & $0.002 *$ & $0.04 \mathrm{~ns}$ \\
\hline Year $\times$ M & 2 & $236069.4 \mathrm{~ns}$ & $0.0024 \mathrm{~ns}$ & $0.018 \mathrm{~ns}$ & $0.02 \mathrm{~ns}$ & $0.0004 \mathrm{~ns}$ & $0.008 \mathrm{~ns}$ \\
\hline Year $\times \mathrm{S} \times \mathrm{M}$ & 4 & $187122.3 \mathrm{~ns}$ & $0.0028 \mathrm{~ns}$ & $0.086 \mathrm{~ns}$ & $0.12 \mathrm{~ns}$ & $0.0003 \mathrm{~ns}$ & $0.07 \mathrm{~ns}$ \\
\hline Error & 24 & 238106.3 & 0.022 & 0.10 & 0.23 & 0.0006 & 0.10 \\
\hline $\mathrm{CV}(\%)$ & & 2.87 & 5.19 & 8.50 & 2.70 & 8.24 & 6.49 \\
\hline
\end{tabular}

RWC: relative water content; STA: stearic acid; OLA: oleic acid; LINO: linoleic acid; ARA: arachidic acid and LINK: linolenic acid, $\mathrm{ns}$, not significant at the 0.05 probability level. *Significant at the 0.05 probability level. ** Significant at the 0.01 probability level.

Furthermore, by species, G. intraradices was more effective at improving these traits than $G$. mosseae (Table 4). The highest RWC was found in the inoculation treatment with $G$. intraradices in all irrigation regimes and both years. Non inoculation showed the lowest SPAD, and it was 12.2 and $14.2 \%$ lower than inoculation with $G$. intraradices (which had a maximum SPAD value) in 2014 and 2015, respectively (Table 4). The interaction between mycorrihzal and water deficit stress was significant and the mean comparison of the combined treatments (Table 6) showed that $G$. intraradices inoculation remarkably increased the SPAD and RWC when compared to the inoculation treatment under normal irrigation, mild and extreme water deficit condition (some data not shown).

\subsection{Seed weight and seed yield}

The analysis of variance showed that there were significant effects from the irrigation and mycorrhiza treatments (Table 3). There was no significant difference between the two-way interactions of Irrigation $\times$ Year. The highest and lowest seed weights, respectively, were obtained from well water and extreme water deficit conditions. The data in Table 4 shows that seed weight increased with the inoculation treatment with mycorrhiza compared to the control treatment and the highest seed weight was obtained under the inoculation of $G$. intraradices in all irrigation regimes.

Mean comparison showed that mild and extreme limited irrigation significantly decreased seed yield by 18.7 and $31.4 \%$ in 2014 and 18.1 and $31.9 \%$ in 2015 when compared to the control (Table 4). As shown in Table 3, regardless of the irrigation treatment, mycorrhiza inoculation with $G$. intraradices in 2015 produced the highest seed yield $\left(4986 \mathrm{Kg} \cdot \mathrm{ha}^{-1}\right.$ ); whereas in 2014 the non inoculation treatment produced the lowest seed yield $\left(3824 \mathrm{Kg} \cdot \mathrm{ha}^{-1}\right)$. Although mycorrhiza inoculation improved seed yield in all irrigation regimes, its effect was more obvious under mild water deficit conditions in both years (data not shown). In both years, the application of mycorrhiza notably increased the seed yield but the effect was stronger from inoculation with $G$. intraradices (table 4). Seed yield was not affected by the two-way interaction of 


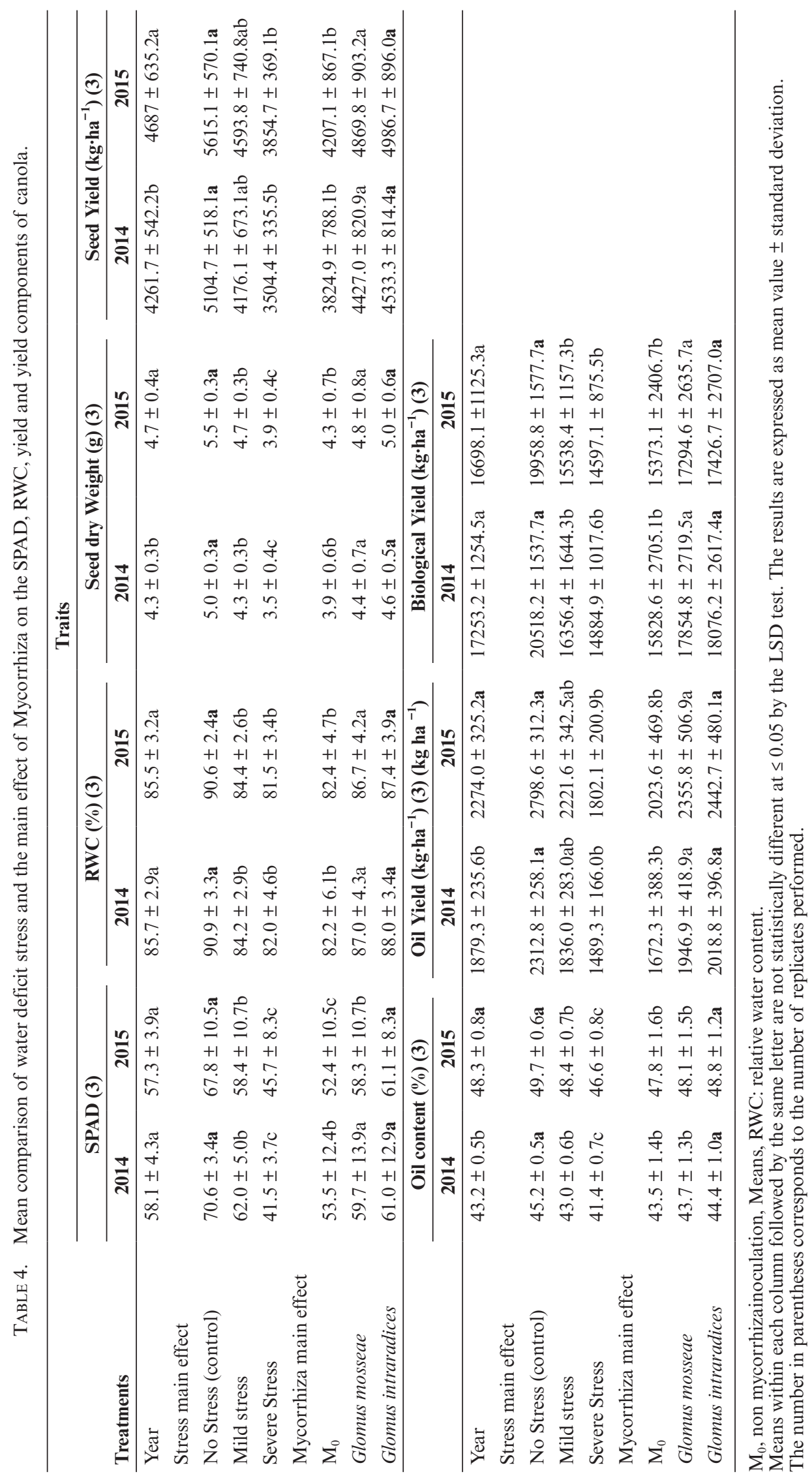



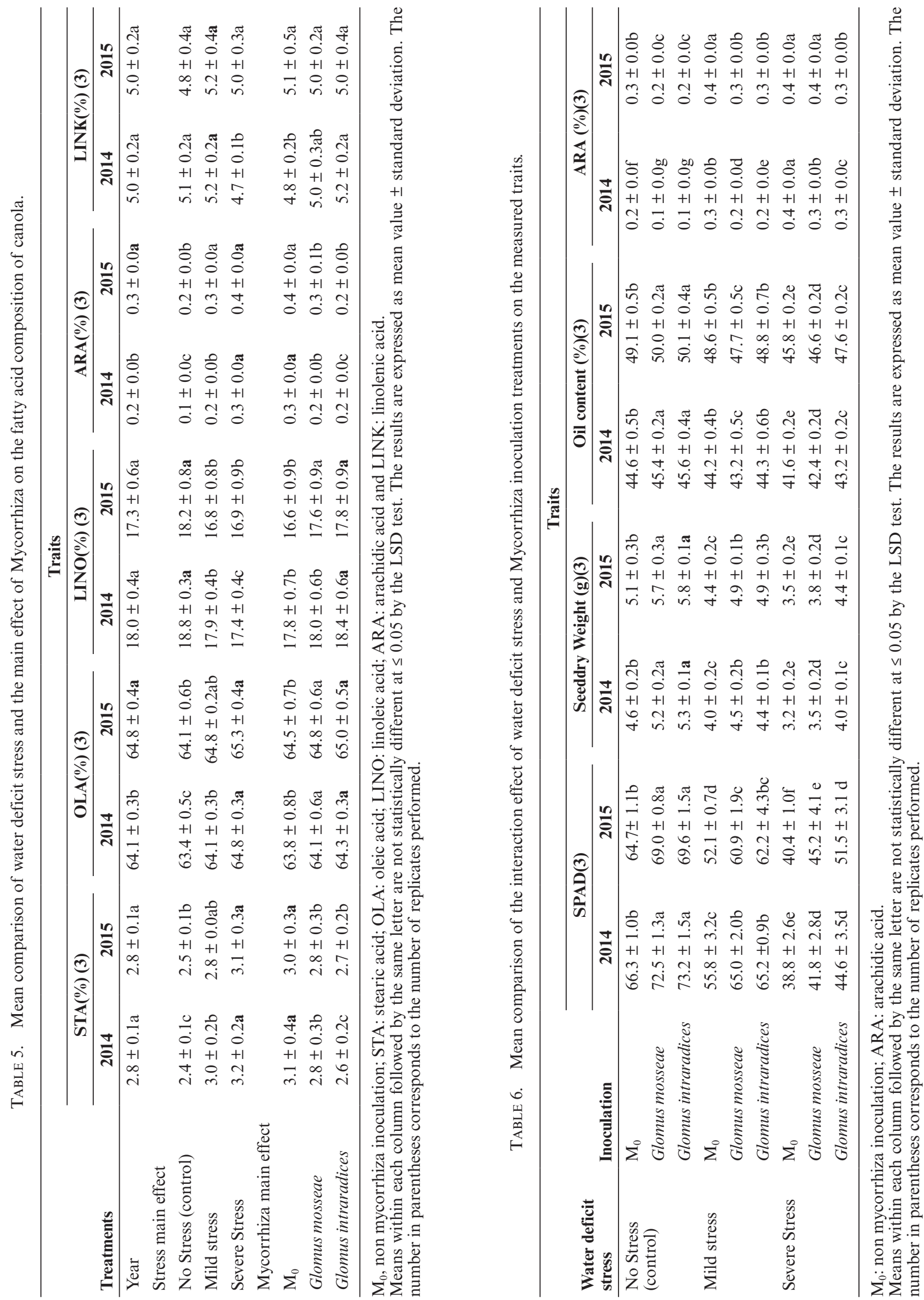
Irrigation $\times$ Mycorrhiza. Regardless of water deficit intensity, the seed yield from inoculated plants was higher than from the non inoculated plants.

\subsection{Oil percentage}

Oil percentage increased by $9 \%$ in 2015 compared to 2014 (Table 4). In both years, water deficit stress decreased oil percentage, and this impact was more pronounced in 2014 than in 2015. Oil percentage in the mild and extreme water deficit conditions was 4.94 and $8.44 \%$ and 2.75 and $6.24 \%$ lower than well water conditions in 2014 and 2015, respectively (Table 4). The mean comparison of mycorrhiza inoculation showed that oil percentage was significantly higher in the inoculation treatment than in non inoculation treatments (Table 4). Plant inoculation with $G$. intraradices presented higher oil percentages in comparison with non inoculation plants and plants with G. mosseae, which were grown under well and deficit water condition. Indeed, among all treatments, maximum and minimum oil contents were obtained with $G$. intraradices inoculation under well water irrigation (50.18 and $45.80 \%$ in 2014 and 2015, respectively) and non inoculation treatment under extreme water deficit conditions (45.61 and $41.64 \%$ in 2014 and 2015, respectively). The two mycorrhiza species were different in their potential, and of two fungal species, G. intraradices performed more effectively while G. mosseae responded less effectively.

\subsection{Oil yield and biomass yield}

Seed oil yield and biological yield responded significantly to the irrigation regimes and mycorrhiza inoculation (Table 4). The oil yield increased by $17 \%$ in 2015 compared to 2014 , mainly because of more favorable climate conditions (Tables 2 and 4). Drought intensity significantly decreased RWC, SPAD, seed weight, seed yield and seed oil percentage (Tables 3 and 4). There were no significant differences between the mixed irrigation treatment and mycorrhiza inoculation. When compared to well water irrigation, the implementation of mild and extreme water deficit stress reduced the oil yield by 20.5 and $35.5 \%$ in 2014 and 20.2 and $35.3 \%$ in 2015. Regardless of water irrigation levels, the oil yield responded positively to the main effect of mycorrhiza inoculation and compared to the control treatment, the two fungal species increased the oil yield (Table 4). However, there was no significant difference between the two mycorrhiza species but G. intraradices was shown to be more efficient than the other. Similar to oil yield, biomass yield was only affected by the irrigation regime and mycorrhiza inoculation (Table 3). Water deficit stress had a negative impact on biomass yield, indicating that water stress decreased assimilate productions.
Biomass yield declined by 20 and $22 \%$ under mild conditions and by 27 and $26 \%$ under extreme water deficit stress compared to the control in 2014 and 2015, respectively. Biomass yield from the seeds inoculated with G. mosseae and G. intraradices, respectively, was increased by 11 and $12.2 \%$ in 2014 and 11.2 and $11.7 \%$ in 2015 compared to non inoculation (Table 4). Furthermore, there were no significant differences between the interaction of irrigation regime and mycorrhiza inoculation. However, the highest biomass was obtained in inoculated plants with $G$. intraradices under well water condition (data not shown).

\subsection{Fatty acid percentages}

The analysis of variance results showed that the STA, OLA, LINO, ARA and LINK were influenced by the main effect of limited irrigation and mycorrhiza species in both years except for LINK in 2015 (Table 3). The interaction of Irrigation $\times$ mycorrhiza was only significant for ARA. In the both years, there was a linear response to drought stress and the highest levels of STA, OLA and ARA were obtained in the extreme water deficit condition (Table 5). However, the impact of limited irrigation on LINO was the inverse of STA, OLA and ARA. The maximum percentage of LINO was yielded under well water irrigation. There were significant effects of irrigation regimes on LINK in 2014, although in the second year the response to this treatment was not significant.

There were significant responses of fatty acids to mycorrhiza inoculation. $G$. intraradices produced the highest LINO and LINK with 3 and $6 \%$ higher in 2014 and 6\% higher in 2015 than non inoculation plants, respectively. Instead, compared to the control, the plants treated with mycorrhiza decreased the content of STA, OLA and ARA in both years (Table 5). The results showed that only ARA was affected by Irrigation regimes $\times$ mycorrhiza interaction (Table 6). Across all treatments, the highest ARA percentage was obtained under extreme water deficit and non inoculation treatment with averages of $0.4 \%$, respectively.

\section{DISCUSSION}

These data show that non inoculated plants, grown either under adequate or limited irrigation, showed the lowest SPAD values. Water shortage stress also had a negative influence on SPAD values. In contrast, the maximum SPAD rate was achieved in inoculated plants that were not affected by any water deficit stress. These finding have also been observed by other researcher. Goksoy et al., (2004) reported that a high SPAD value was obtained when the adequate irrigation was applied. One major reason for a low SPAD value under conditions of 
water shortage is the reduction in the mass flow of water through the soil under mild and severe drought stress treatment conditions, consequently decreasing $\mathrm{N}$ absorption by the plants. In general, the SPAD value was ameliorated by the mycorrhiza application compared to the control treatment. An increased greenness index due to plant colonization with PGPR has been reported by Rojas-Tapias et al., (2012). The positive effects of these microorganisms are attributed to their sufficiency in the uptake of nutrients with dissolved immobilized nutrients (Ahemad and Kibret, 2014), producing phytohormones such as abscisic acid which are involved in water loss regulation by changing the plant's stomatal sensivity and stress signal transduction pathways (Yamamuro et al., 2016). This results in higher water absorption by increasing the length and density of the lateral root hair, which leads to a higher surface area for exchange with the rhizosphere (Adesemoye and Ugoji, 2009). It has also been reported that plants colonized with PGPR were able to promote plant growth due to morphological modifications in their coleoptile xylem structure. This was attributed to an increased uptake in the indol-3-pyruvate decarboxylase gene and increased IAA synthesis (Pereyra et al., 2012).

During both years, in the normally irrigated plants, the RWC was increased in the inoculated plants compared to non inoculated ones. Elevated levels of RWC have been reported in Jatropha curcas (Kumara et al., 2009). It should also be mentioned that increases in RWC under extreme water deficit and inoculated with $G$. intraradices indicated that plants treated with PGPR had more hydraulic conductivity in their roots compared to untreated plants under low water conditions. The increase in root conductance is related to a longer root and an improvement in the root system stimulated by mycorrhizae. Notably, significant and positive correlations between the RWC and SPAD value $\left(\mathrm{r}^{2}{ }_{2014}=0.77\right.$ and $\mathrm{r}^{2}{ }_{2015}=0.81$, data not shown) demonstrated that fungal symbiosis increased the absorption of water and nutrients from the soil, leading to increased plant growth and survival under water shortage conditions.

Seed weight and seed yield in canola was lower under drought stress, indicating that deficit irrigation decreased assimilate allocation to seeds. Drought stress decreased canola yield because of a reduction in leaf size and stem extension which resulted in lower PAR absorption efficiency by the crops and decreased seed yield due to a reduced harvest index (some data are not shown). It is worth mentioning that under limited water conditions, more assimilate is allocated to the root, resulting in a higher rate of root inoculation and hyphae. It was found that a higher seed weight was achieved when the adequate irrigation was applied (Safavi Fard et al., 2018). Mycorrhiza species, especially by $G$. intraradices, improved seed weight and seed yield in plants exposed to various drought intensities. Increased yield and yield components due to plant inoculation with PGPR (Paenibacillus polymyxa and Rhizobium tropici) have been reported (Figueiredo et al., 2008). The stimulating effects of mycorrhiza fungi might be due to their efficiency in root growth, better nutrient quality and higher relative water content through the plants' roots. During both years, for normal and limited water conditions, seed weight and seed yield showed significant differences among fungal colonization treatments. These results were also observed by Figueiredo et al., (2008) in common bean plants inoculated with two Paenibacillus polymyxa strains. Increasing seed weight and seed yield under extreme water deficit stress and inoculation plants illustrated that these plants had more hydraulic conductivity in their roots at low water conditions. The increased root conductance is related to greater water acquisition by hyphae (Kaushal and Wani, 2016) exchange in the architecture of the root system by induced longer root and increasing root mass (Mantelin and Touraine, 2004), which finally affected water status, transpiration rate and crop yield. Notably we found that between two different mycorrhiza fungi, $G$. intraradices was more effective than $G$. mosseae, so that an increase of 4 and 2\% (averaged over two years) in seed weight and seed yield were observed. It is obvious that various mycorrhiza fungi have different root inoculation capacities and different effects on plant growth and development.

Oil content and oil yield were affected by drought stress and mycorrhiza inoculation (Table 4). Decreases in oil yield percentages with water limitation may be due to the reduction in the length of the growing season (Safavi Fard et al., 2018). Cohen et al., (2009) also found that stressed plants resulted in more ABA in the leaves. This ABA transmits to the seed and contributes to the decline in seed oil percentage. A higher temperature during the period of the seed development phase in 2014 could be the reason for the variation in the two years. It has been found that a high temperature during seed filling causes many empty achenes and decreases oil percentage (Safavi Fard et al., 2018). The mean oil content in $G$. intraradices treatment compared to the control was improved by 2.0 and $2.1 \%$ in 2014 and 2015 , respectively. It was reported that the inoculation of Origanum majorana L. with PGPR produced a higher oil percentage compared to non inoculated plants (Banchio et al., 2008). In the present study we found that colonization by $G$. intraradices significantly increased oil percentage in the plants treated with various intensities of water deficit stress. Improvements in oil percentage due mycorrhiza inoculation might be related to enhanced solubility and the availability of phosphorus. 
Mycorrizal activities increased the release of $\mathrm{CO}_{2}$, which turned into $\mathrm{H}_{2} \mathrm{CO}_{3}$ in the soil solution. The resulting week acid could be dissolved by phosphorus-containing minerals, thereby increasing $\mathrm{P}$ availability. Previous studies indicated that the higher $\mathrm{P}$ absorption in mycorrhiza plants under stress conditions produced higher amounts of roots, which was beneficial under stress conditions (Mantelin and Touraine, 2004). Also, according to Bouwmeester et al., (2007) the synthesis of some compounds such as organic acids and organic ligands by PGPRs increased the concentration of inorganic phosphorus sources. Because phosphorus is an important nutrient in phospholipid structures, an increase in the soluble form of $\mathrm{P}$ can accelerate the metabolic pathways leading to oil production.

In two years, dry matter values were significantly higher in well irrigation compared to the water deficit condition. The reduction in dry matter under water shortage stress was probably related to decreased water uptake and impaired nutrient absorption and mobilization from root to shoot due to limited transpiration rate and membrane permeability (Safavi Fard et al., 2018). Indeed, there was a thin layer of nutrients around the soil particles, resulting in a poor diffusion of ions into the root cells (Kumara, 2009). As plant biomass or seed yield are made from recently accumulated or formerly stored resources, the reduction in water availability probably yielded low biomass and seed formation. Generally, limited water stress could cause a negative effect on dry matter by changing both source and sink for assimilation. In the study of Nazeri et al., (2018), it was reported that biomass yield can be affected by drought stress. Improved dry matter in plants colonized with PGPR has been reported for a number of crops (Casanovas et al., 2002; Creus et al., 2004). However, the effects of PGPR inoculation on plant biomass varied depending on the fungal species. It should also be mentioned that the $G$. intraradices was isolated from the arid region in Iran which increased its capability to grant drought tolerance of the host plant. In contrast $G$. mosseae fungi was originated from the humid area of Iran. Additionally, it has been shown that the symbiotic behavior of rhizobacteria depends on its ability to inoculate the root of the host plant rapidly and extensively (Adesemoye and Ugoji, 2009). Therefore, the increased growth of canola observed following fungal colonization was probably due to the solubilization of phosphates, the oxidation of sulphate, the increase in nitrate availability and enhanced production of auxin and cytokinins (Mantelin and Touraine, 2004). An increased formation of lateral roots leads to enhanced root surface area and access to soil nutrients. Similarly to our findings, inoculation with rhizosphere microorganisms increased IAA production, and root growth and finally improved dry matter and seed yield in crop plants (Verma et al., 2010).

With regards seed oil composition, we observed an increase in saturated fatty acids in water deficit stress with respect to normal conditions. Stress conditions may alter the efficiency of these steps and result in different oil compositions. Aslam et al., (2009) reported that a stress situation affected the activity of oleate desaturation. In fact, stress treatment caused a marked increase in the saturated/ unsaturated ratio (data not shown). Limited water stress may produce a decrement in the desaturation of stearic to oleic acid, resulting in a decrease in oleic acid (Aslam et al., 2009). Similar results have been reported on the effect of drought stress on oil composition in oilseed crops (Safavi Fard et al., 2018). In addition, the synthesis of fatty acids in seeds takes place up to oleic acid in proplastids and after that in cytosol (Steen et al., 2010). Perhaps environmental parameters influenced the composition of fatty acids not only by changing the enzyme activity but also by changing the transport from one organelle to another.

The inoculation of oilseeds with PGPR has been reported to change the quality and quantity of oil (Kaushal and Wani, 2016). The availability of nutrients such as nitrogen may increase the vegetative phase and interrupt protein synthesis. Also, higher nitrogen uptake by canola improved plant growth and development (as evident by higher biomass yield) and therefore enhanced the oil storage sites of the seeds. Arora et al., (2001) reported that inoculated plants with rhizobacteria microbes increased the amount of soil nutrients ( $\mathrm{Fe}$ and $\mathrm{Mo}$ ) and thus enhanced the process of symbiotic nitrogen fixation. Additionally, nitrogen has an important role in the division and development of plant cells containing oil (Keshavarz et al., 2019). A positive and significant correlation of increased seed oil composition with nitrogen supplement in oil seed crops has also been reported (Martínez-Ballesta et al., 2013).

\section{CONCLUSIONS}

Water deficit prevents plant growth and development due to damaged biochemical and physiological mechanisms. Our study showed a clear improvement in seed quality attributes (oil percentage and fatty acid composition) with mycorrhiza treatment. The mechanisms elicited by bacteria such as osmotic adjustment enhanced the production of auxin and cytokinins and the availability of nutrients which play a vital role in improving plant growth and production. RWC and SPAD values were also higher in inoculated plants in both years, reflecting the positive effects on yield and yield components. We conclude that inoculated plants may improve canola profitability and increase the long-term sustainability of oil seed production systems in arid and 
semi-arid regions. Finally, the application of $G$. intraradices could be more efficient in the cultivation of plants under arid and semi-arid conditions, where water is the most important factor in determining plant growth and yield.

\section{ACKNOWLEDGMENTS}

This research work was supported by Tarbiat Modares University, Iran. Also, the authors thank Dr. Rachel Rubin for critical reading of the manuscript.

\section{NOTE}

The authors declare no competing financial interest.

\section{REFERENCES}

Adesemoye AO, Ugoji EO. 2009. Evaluating Pseudomonas aeruginosa as plant growth-promoting rhizobacteria in West Africa. Arch. Phytopathol. Plant. Prot. 42, 188-200. https:// doi.org/10.1080/03235400601014791

Ahemad M, Kibret M. 2014. Mechanisms and applications of plant growth promoting rhizobacteria: current perspective. King. Saud. Univ. Sci. 26, 1-20. https://doi.org/10.1016/j. jksus.2013.05.001

Anjum S, Xie X, Wang L, Saleem M, Man C, Lei W. 2011. Morphological, physiological and biochemical responses of plants to drought stress. J. Afr. Agric. Res. 6, 2026-2032.

Arora NK, Kang SC, Maheshwari DK. 2001. Isolation of siderophore-producing strains of Rhizobium meliloti and their biocontrol potential against Macrophomina phaseolina that causes charcoal rot of groundnut. Curr. Sci. 81 (6), 673-677.

Arvin P, Vafabakhsh J, Mazaheri D, Noormohamadi Gh, Azizi M. 2012. Study of Drought Stress and Plant Growth Promoting Rhizobacteria (PGPR) on Yield, Yield Components and Seed Oil Content of Different Cultivars and Species of Brassica Oilseed Rape. Ann. Biol. Res. 3 (9), 44444451.

Aslam MN, Nelson MN, Kailis SG, Bayliss KL, Speijeres J, Cowling WA. 2009. Canola oil increases in polyunsaturated fatty acids and decreases in oleic acid in drought-stressed Mediterranean-type environments. Plant Breeding. 128, 348-355. https://doi.org/10.1111/j.1439-0523.2008.01577.x

Banchio E, Bogino PC, Zygadlo J, Giordano W. 2008. Plant growth promoting rhizobacteria improve growth and essential oil yield in Origanum majorana L. Biochem. Syst. Ecol. 36, 766-771. https://doi.org/10.1016/j.bse.2008.08.006

Baux A, Hebeisen T, Pellet D. 2008. Effects of minimal temperatures on low-linolenic rapeseed oil fatty acid composition. Eur. J. Agron. 29, 102-107. https://doi.org/10.1016/j. eja.2008.04.005

Bouwmeester HJ, Roux C, Lopez-Raez JA, Becard G. 2007. Rhizosphere communication of plants, parasitic plants and AM fungi. Trends. Plant. Sci. 12, 224-230. https://doi. org/10.1016/j.tplants.2007.03.009

Budge SM, Barry C. 2019. Determination of squalene in edible oils by transmethylation and GC analysis. MethodsX. 6, 15-21. https://doi.org/10.1016/j.mex.2018.12.001

Casanovas EM, Barassi CA, Sueldo RJ. 2002. Azospirillum inoculation mitigates water stress effects in maize seedlings. Cereal. Res. Commun. 30, 343-350.

Chen J, Xu W, Velten J, Xin Z, Stout J. 2012. Characterization of maize inbred lines for drought and heat tolerance. J. Soil. Water. Conserv. 67, 354-364. https://doi.org/10.2489/ jswc. 67.5.354

Cohen AC, Travaglia CN, Bottini R, Piccoli PN. 2009. Participation of abscisic acid and gibberellins produced by endophytic Azospirillum in the alleviation of drought effects in maize. Botanique 87, 455-462. https://doi. org/10.1139/B09-023

Creus CM, Sueldo RJ, Barassi CA. 2004. Water relations and yield in Azospirillum-inoculated wheat exposed to drought in the field. Can. J. Bot. 82, 273-281. https://doi. org/10.1139/b03-119

Eyni-Nargeseh H, AghaAlikhani M, Shirani Rad AH, Mokhtassi-Bidgoli A, Modarres Sanavy SAM. 2020. Late season deficit irrigation for water-saving: selection of rapeseed (Brassica napus) genotypes based on quantitative and qualitative features. Arch. Agron. Soil. Sci. 66 (1), 126-137. https://doi.org/10.1080/03650340.2019.1602866

Figueiredo MFV, Burity HA, Martínez CR, Chanway CP. 2008. Alleviation of drought stress in the common bean (Phaseolus vulgaris L.) by co-inoculation with Paenibacillus polymyxa and Rhizobium tropici. Appl. Soil Ecol. 40, 182-188. https://doi.org/10.1016/j.apsoil.2008.04.005

Goksoy AT, Demirb AO, Turana ZM, Dagustu N. 2004. Responses of sunflower (Helianthus annuus L.) to full and limited irrigation at different growth stages. Field Crop Res. 87, 167-178. https://doi.org/10.1016/j.fcr.2003.11.004

Gunasekera CP, Martin LD, Siddique KHM, Walton GH. 2006. Genotype by environment interactions of Indian mustard (Brassica juncea L.) and canola (Brassica napus L.) in Mediterranean-type environments II. Oil and protein concentrations in seed. Eur. J. Agron. 25, 3-21. https://doi. org/10.1016/j.eja.2006.02.001

Huang J, Yu H, Guan X, Wang G, Guo R. 2016. Accelerated dryland expansion under climate change. Nat. Clim. Change. 6, 166-171. https://doi.org/10.1038/nclimate2837

Kaushal M, Wani SP. 2016. Plant-growth-promoting rhizobacteria: drought stress alleviators to ameliorate crop production in drylands. Ann. Microbiol. 66, 35-42. https://doi. org/10.1007/s13213-015-1112-3

Keshavarz H, Modarres-Sanavy SAM, Mahdipour Afra M. 2018. Organic and Chemical Fertilizer Affected Yield and Essential Oil of Two Mint Species. J. Essent Oil. Bear. Pl. 21 (6), 1674-1681. https://doi.org/10.1080/09720 $60 \times .2018 .1497545$

Kumara A, Sharma S, Mishra S. 2009. Effect of alkalinity on growth performance of Jatropha curcas inoculated with PGPR and AM fungi. Journal. Phytol. 1 (3), 177-184.

Mantelin S, Touraine B. 2004. Plant growth-promoting rhizobacteria and nitrate availability: impacts on root development and nitrate uptake. J. Exp. Bot. 55, 27-34. https://doi. org/10.1093/jxb/erh010

Martínez-Ballesta C, Moreno D, Carvajal M. 2013. The Physiological Importance of Glucosinolates on Plant Response to Abiotic Stress in Brassica. Int. J. Mol. Sci.14, 11607-11625. https://doi.org/10.3390/ijms140611607

Mokhtassi-Bidgoli A, AghaAlikhani M, Nassiri-Mahallati M, Zand E, Gonzalez-Andujar JL, Azari A. 2013. Agronomic performance, seed quality and nitrogen uptake of Descurainia sophia in response to different nitrogen rates and water regimes. Ind. Crop. Prod. 44, 583- 592

Nazeri P, Shirani Rad AH, ValadAbadi SA, Mirakhori M, Hadidi Masoule E. 2018. Effect of sowing dates and late season water deficit stress on quantitative and qualitative traits of canola cultivars. Outlook. Agr. 47 (4), 291-297. https://doi.org/10.1177/0030727018793658

Pereyra MA, Garcia P, Colabelli MN, Barassi CA, Creus CM. 2012. A better water status in wheat seedlings induced by Azospirillum under osmotic stress is related to morphological changes in xylem vessels of the coleoptile. Appl. Soil. Ecol. 53, 94-97. https://doi.org/10.1016/j. apsoil.2011.11.007

Qian P, Schoenau JJ, Karamanos RE. 1994. Simultaneous extraction of available phosphorus and potassium with a new soil test: A modification of Kelowna extraction. Commun. Soil Sci. Plan. 25, 627-635. https://doi. org/10.1080/00103629409369068

Rahdari P, Hoseini SM. 2012. Drought stress. A review. Int. J. Agron. Plant Prod. 3, 443-446.

Rojas-Tapias D, Moreno-Galván A, Pardo-Díaz S, Obando M, Rivera D, Bonilla R. 2012. Effect of inoculation with 
plant growth-promoting bacteria (PGPB) on amelioration of saline stress in maize (Zea mays). Appl. Soil Ecol. 61, 264-272. https://doi.org/10.1016/j.apsoil.2012.01.006

Safavi Fard N, Heidari Sharif Abad H, Shirani Rad AH, Majidi Heravan E, Daneshian J. 2018. Effect of drought stress on qualitative characteristics of canola cultivars in winter cultivation. Industrial Crops and Products 114, 87-92. https:// doi.org/10.1016/j.indcrop.2018.01.082

SAS Institute Inc. 2002. The SAS System for Windows, Release 9.0. Cary, NC, USA: Statistical Analysis Systems Institute.

Steen E, Kang Y, Bokinsky G, Hu Zh, Schirmer A, McClure A, Cardayre S, Keasling J. 2010. Microbial production of fatty-acid-derived fuels and chemicals from plant biomass. Nature 463, 559-562. https://doi.org/10.1038/nature08721

Verma JP, Yadav J, Tiwari NK, Lavakush SV. 2010. Impact of plant growth promoting rhizobacteria on crop production.
Int. J. Agric. Res. 5, 954-983. https://doi.org/10.3923/ ijar.2010.954.983

Walkley A, Black IA. 1934. An examination of Degtjareff method for determining soil organic matter, and proposed modification of the chromic acid tritation method. Soil Sci. 37, 29-38. https://doi.org/10.1097/00010694-193401000-00003

Yamamuro C, Zhu JK, Yang Z. 2016. Epigenetic Modifications and Plant Hormone Action. Mol. Plant. 9, 57-70. https:// doi.org/10.1016/j.molp.2015.10.008

Zhang M, Barg R, Yin M, Gueta-Dahan Y, Leikin-Frenkel A, Salts Y, Shabtai S, Ben-Hayyim G. 2005. Modulated fatty acid desaturation via overexpression of two distinct omega-3 desaturases differentially alters tolerance to various abiotic stresses in transgenic tobacco cells and plants. Plant J. 44 (3), 361-371. https://doi.org/10.1111/j.1365313X.2005.02536.X 